Informe sobre el proyecto de ley que establece la responsabilidad legal de las personas jurídicas en los delitos de lavado de activos, financiamiento del terrorismo y delitos de cohecho que indica, mensaje $\mathrm{N}^{\circ}$ 018-357/

Jean Pierre Matus Acuña

páginas 285 - 306

\title{
INFORME SOBRE EL PROYECTO DE LEY QUE ESTABLECE LA RESPONSABILIDAD LEGAL DE LAS PERSONAS JURÍDICAS EN LOS DELITOS DE LAVADO DE ACTIVOS, FINANCIAMIENTO DEL TERRORISMO Y DELITOS DE

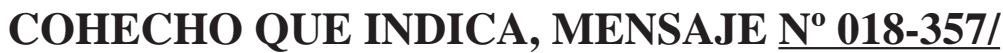

\author{
Jean Pierre Matus Acuña*
}

\begin{abstract}
A la Honorable Sra. Diputada Laura Soto

Presidenta de la Comisión de Constitución, Legislación y Justicia Honorable Cámara de Diputados de Chile /
\end{abstract}

Santiago, 28 de mayo de 2009

Informe sobre el proyecto de ley que establece la responsabilidad legal de las personas jurídicas en los delitos de lavado de activos, financiamiento del terrorismo y delitos de cohecho que indica, Mensaje $\underline{N^{\circ} 018-357 /}$

Honorable Sra. Presidenta:

Tengo el honor de someter a su consideración y a la de los Honorables Sres. Diputados de la Comisión que preside, la versión escrita del informe que, sobre el proyecto del ley de la referencia, evacuase verbalmente en la sesión de la Comisión de Constitución, Legislación y Justicia de la Honorable Cámara de Diputados, el día 19 de mayo del corriente.

El informe se divide en tres partes: en la primera se hace referencia al contexto global en

* Doctor en Derecho, Profesor Titular de Derecho Penal de la Universidad de Talca y Director del Centro de Estudios de Derecho Penal de dicha Casa de estudios superiores. Correo electrónico: jpmatusa@utalca.cl 
que se ha desarrollado e impulsado en el derecho internacional y comparado la necesidad de establecer la responsabilidad penal de las personas jurídicas; en la segunda, a los fundamentos del Mensaje y nuestras obligaciones en materia de derecho internacional al respecto; y en la tercera, se plantean las observaciones generales al texto del proyecto de ley que se informa, así como observaciones particulares y sugerencias de perfeccionamiento de ciertas disposiciones concretas del mismo, que someto a vuestra consideración.

\section{El contexto global de la necesidad de establecer sanciones eficaces, proporcionales y disuasivas para las personas jurídicas}

William Clifford, Secretario Ejecutivo del Cuarto Congreso de las Naciones Unidas sobre Prevención del Delito y Tratamiento del Delincuente, realizado en Kyoto (Japón) entre el 17 y el 26 de agosto de 1970, describía así, en los trabajos preparatorios de dicho Congreso, el interés de la ONU en el delito:

"El problema del crimen en el mundo interesa a la ONU por muchas razones. Evidentemente, está directamente vinculado al objetivo principal de la Organización de sus Estados miembros: la paz mundial. Porque la paz es indivisible y no puede considerarse independientemente de la acción recíproca de los pueblos, tanto en la esfera interna, como a un lado y otro de las fronteras. Cabe pensar que media una gran distancia entre los crímenes cometidos por asociaciones de delincuentes, los robos a mano armada, los abusos de confianza y la diplomacia internacional y las negociaciones entre los miembros del Consejo de Seguridad. Sin embargo, los asesinatos, la piratería, los secuestros internacionales han causado guerras. Hoy en día el tráfico ilícito de estupefacientes, el contrabando de armas, las exportaciones ilegales de oro, el secuestro de diplomáticos, el desvío de aeronaves y su sabotaje, la protección concedida a los criminales que huyen, constituyen causas de tensión y conflictos internacionales..."

Naturalmente, en una época donde no se hablaba de la "globalización", las palabras recién transcritas podrían haberse considerado como un simple discurso interesado. Sin embargo, ellas parecen describir sucesos tan recientes como los atentados del 11-S, la piratería en los mares de Somalia, la proliferación del narcotráfico, la corrupción en las licitaciones internacionales y, en general, todos los hechos delictivos que, por su propia dinámica, traspasan

ONU, Chronique mensuelle. Vol. VII, n 5, 1970, p. 73. Citado por MARTÍ DE VESES, Ma. Del Carmen, "El Derecho internacional público y el consumo y tráfico de drogas y estupefacientes". En: AUTORES VARIOS. Delitos contra la Salud Pública. Tráfico ilegal de drogas tóxicas o estupefacientes. Valencia: Universidad de Valencia, 1977, p. 257-295, p. 258. 
Informe sobre el proyecto de ley que establece la responsabilidad legal de las personas jurídicas en los delitos de lavado de activos, financiamiento del terrorismo y delitos de cohecho que indica, mensaje $\mathrm{N}^{\mathrm{o}}$ 018-357/

las fronteras y adoptan un carácter "transnacional". En este contexto, es claro que el Derecho penal internacional como un todo (y no sólo el denominado "derecho penal de la emergencia") ${ }^{2}$ no se encuentra únicamente legitimado por su función en el ordenamiento estatal interno, cualquiera que sea la que se le asigne, sino por su eventual utilidad como instrumento para la conservación de "la paz y seguridad mundial", ${ }^{3}$ por medio no sólo del mantenimiento de los derechos humanos básicos, como acontece con las reglas del derecho internacional penal, ${ }^{4}$ sino también de las más pedestres reglas comunes para la prevención y control de los delitos comunes que pueden tener trascendencia internacional.

Es por ello que, más allá de la existencia de fuertes intereses económicos en el origen de estas reglas, ${ }^{5}$ burocracias internacionales dependientes (p. ej., la OCDE, la UNODC y las múltiples ONG de protección de "víctimas") y "emprendedores morales atípicos" interesados; ${ }^{6}$ las Convenciones que regulan los delitos de trascendencia internacional (sujetas al procedimiento de ratificación y, por tanto, ajenas a la crítica de la falta de legitimidad democrática de que son objeto organismos supranacionales como la Comisión Europea $)^{7}$ parecen comprender un conjunto de hechos que, según cada uno de los Estados Parte, son merecedores de pena en su

Críticamente, ver al respecto BRANDARIZ G. José Ángel.,"Itinerarios de evolución del sistema penal como mecanismo de control social en las sociedades contemporáneas". En: FARALDO C., Patricia (Directora), Nuevos retos del Derecho Penal en la era de la globalización. Valencia: Tirant Lo Blanch, 2004, p. 15-64, especialmente p. 54-60. También críticamente contra este concepto, aplicado precisamente a los delitos terroristas, VILLEGAS, Myrna, "Los delitos de terrorismo en el Anteproyecto de Código Penal". Polít. crim. no 2, A3, 2006, p. 1-31, p. 3.

3 Las dificultades de dotar de contenido a esta expresión pueden verse en COMBACAU, Jean; SUR, Serge, Droit international public. Paris: Montchrestien, 1993, 821 p., p. 619 y siguientes.

$4 \quad$ AMBOS, Kai, Der allgemeine Teil des Vólkerstrarechts. Ansätze einer Dogmatisierung. $2^{\mathrm{a}}$ ed. Berlin: Duncker \& Humblot, 2004, 1057 p p. 66 y siguiente, siguiendo a Höffe y a Habermas, ve en la protección de estos derechos la función de la "República mundial" en formación.

5 Como pone énfasis, respecto a las relativas a la corrupción, ABANTO, Manuel. "La lucha contra la corrupción en un mundo globalizado". En LOSANO G., Mario; MUÑOZ CONDE, Francisco (coordinadores), El derecho ante la globalización y el terrorismo. <<Cedant ama togae >>. Valencia: Tirant Lo Blanch, 459 p., p. 273-327, p. 313-322.

$6 \quad$ SILVA SÁNCHEZ, Jesús Mª., La expansión del derecho penal. Aspectos de la política criminal en las sociedades postindustriales. $2^{\mathrm{a}}$ ed., revisada y ampliada. Madrid: Civitas 2001, 167 p., p. 66-69, 81-102.

7 A modo de referencia, ver al respecto la encendida discusión iniciada en Alemania por HEFENDELF, Roland, "Europäischer Umweltschutz: Demokratiespritze für Europa oder Brüsseler Putsch". Zeitschrift für Internationale Strafrechtsdogmatik. 4/2006, p. 161-167; "Europäisches Strafrecht: bis wohin und nicht weiter?". Zeitschrift für Internationale Strafrechtsdogmatik. 6/2006, p. 229-236; POHL, Tobias, "Verfassungsvertrag durch Richterspruch. Die Entscheidung des EuGH zu Kompetenzen der Gemeinsschaft im Umweltstrafrecht". Zeitschrift für Internationale Strafrechtsdogmatik. 5/2006. p 213-221. Para una visión general y menos apasionada del estado de la cuestión, véase AMBOS, Kai, Internationales Strafrecht. München: C.H. Beck, 2006, 491 p., p.375-403. Sobre la evolución del Derecho europeo en la materia antes del fallo comentado, véase el pionero trabajo de CARNEVALI, Raúl, Derecho penal y derecho sancionador de la Unión Europea. Granada: Comares, 2001, 472 p., donde, conforme al estado de la discusión en ese momento, se afirmaba la inconveniencia de un derecho penal supranacional, decantándose por favorecer un proceso acelarado de armonización y un empleo intesivo del derecho administrativo sancionador (p. 415-424) 
propio ordenamiento interno, con independencia de si son o no cometidos por particulares, "las empresas" o "los poderosos": tanto corrompe las normales relaciones económicas y el Estado de Derecho el sistema de soborno en las licitaciones internacionales que estableció a fines del siglo XX la empresa alemana Siemens, ${ }^{8}$ como el funcionario que exige una prestación miserable por un servicio esencial; del mismo modo que, ya superlativamente, tanto contribuye a la difusión incontrolada de sustancias estupefacientes o psicotrópicas el "dealer" que las distribuye a los alumnos de un colegio, como la empresa de servicios que beneficia del lavado de dineros que de allí proviene. ${ }^{9}$

Lo anterior se refuerza por el hecho de que buena parte de estos "delitos de trascendencia internacional" no son novedosos en modo alguno, salvo en formas completamente casuales de manifestación, derivadas de los avances tecnológicos y las facilidades de comunicación y transporte: el asesinato de personas por motivos políticos o económicos, la corrupción funcionaria, las organizaciones criminales, el tráfico ilícito de productos nocivos para la salud, la piratería, las falsificaciones, la corrupción de menores y el secuestro de personas, e incluso la criminalidad económica, particularmente el lavado de dinero y el aprovechamiento de los efectos de los delitos son todos hechos sancionados de una forma u otra en todos los códigos decimonónicos y aún, entre nosotros, desde las Partidas. ${ }^{10}$

8 Un panorama periodístico de la corrupción en las grandes empresas alemanas a principios de este siglo, puede verse en un reportaje del Frankfurter Allgemeine Zeitung de 20 de abnril de 2007, disponible en http://www.faz.net/

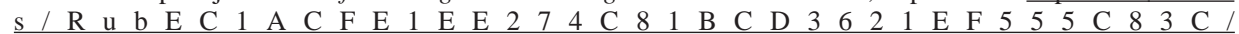
Doc E62354979C73C4AFBBE28AA71930F03AF ATpl Ecommon Scontent.html [visitado el 27.05.2009]. La reacción posterior, incluyendo la elaboración de programas anticorrupción internos, puede verse en la actual página web de Siemens, que ha adoptado, producto de la presión internacional, un modelo estándar de compliance en la "lucha contra la corrupción" [ver: http://w1.siemens.com/responsibility/de/compliance/korruption.htm, visitado el 27.05.2009]

9 Por eso no resulta de recibo, a este respecto, la tesis de GRACIA MARTÍN, Luis, Prolegómenos para la lucha por la modernización y expansión del derecho penal y para la crítica del discurso de la resistencia. Valencia: Tirant Lo Blanch, 2003, p. 190, en el sentido de que, si este derecho penal internacional integrase el que denomina "Derecho penal moderno", tendría como finalidad la "criminalización formal ... del sistema de acción éticosocialmente reprobable de las clases socialmente poderosas". Esta idea, que supondría una asimilación del Derecho penal internacional a una suerte de movimiento socialdemocrático propio de la Europa continental, carece de base empírica en este ámbito, donde confluyen los más diversos sistemas económicos y sociales. Al respecto, ver las lúcidas críticas de PAREDES CASTAÑóN, José M., "Recensión: GRACIA MARTÍN, Luis. Prolegómenos para la lucha por la modernización y expansión del derecho penal y para la crítica del discurso de la resistenciai". Polit. crim. $\mathrm{n}^{\mathrm{o}} 2$, R7, p. 1-27, especialmente p. 20-24.

10 Para justificar este aserto, invito al lector a revisar desprejuiciadamente la primera edición de la obra de PACHECO, Joaquín F., El Código penal concordado y anotado. 3 t. Madrid: Imprenta Saunaque, 1848 (t. I, 551 p. y II, 532 p.) y 1949 (t. III, 503 p.), donde encontrará comentarios del autor y referencias de las Partidas y otros códigos de la época para los siguientes temas "modernos": el asesinato de personas por motivos políticos (p. 108-109 y 125-139, t. II), la corrupción funcionaria (p. 395-530, t. II), las organizaciones criminales (p. 253265, t. II), el tráfico ilícito de productos nocivos para la salud (p. 362-371, t. II), la piratería (p. 112-117 t. II), las falsificaciones (p. 266-331, t. II), la corrupción de menores (p. 134-147, t. III), el secuestro de personas (p. 243255, t. III). Allí podrá observarse que el castigo de las formas preparatorias de comisión del delito y aún de la no 
Informe sobre el proyecto de ley que establece la responsabilidad legal de las personas jurídicas en los delitos de lavado de activos, financiamiento del terrorismo y delitos de cohecho que indica, mensaje $\mathrm{N}^{\mathrm{o}}$ 018-357/

Por lo tanto, si la crítica a este desarrollo del Derecho internacional penal, se dirige al hecho de que, de todas maneras, generaría un "Derecho penal más autoritario de lo normal ... legitimando la creación a nivel nacional de una legislación excepcional en materia de terrorismo, lucha contra la criminalidad organizada, narcotráfico, inmigración ilegal, etc., que no respeta las garantías y derechos fundamentales reconocidos a nivel constitucional y que constituyen las bases del Derecho penal del Estado de Derecho"; ${ }^{11}$ hay que admitir que ella estaría a lo sumo justificada respecto al "cómo" cada Estado y su propia dogmática entienden actualmente la política criminal y las garantías personales, ${ }^{12}$ pero no al "si" los hechos en ellas comprendidas son merecedores de una sanción penal más o menos uniforme, que incluya la responsabilidad penal de las personas jurídicas, en el concierto de las naciones.

\section{Antecedentes y fundamentos de la propuesta contenida en el Mensaje $\mathbf{N}^{0}$ 018-357, que establece la "responsabilidad legal" de las personas jurídicas para ciertos delitos: nuestras obligaciones en el plano del Derecho internacional}

En el Mensaje que establece la "responsabilidad legal” de las personas jurídicas, se mencionan entre sus antecedentes y como sus fundamentos, la concreción en el plano normativo de lo expuesto en el apartado anterior, esto es, la "tendencia" tanto en el derecho comparado

denuncia de éstos, así como la asimilación de la consumación a la tentativa eran propias de los delitos que afectaban a la seguridad del Estado, particularmente cuando se trataba de atentados al soberano; los comentarios de Pacheco sobre la estructura general de los delitos de corrupción funcionaria: "su materia es sumamente extensa; sus preceptos, que deben abarcarla toda, no pueden menos que correr una inmensa escala, desde lo más sencillo a lo más grave" (p. 395, t. II); sobre la necesidad de castigar la falsificación de monedas extranjeras, que "no es nunca una acción que puede practicarse con buen fin" (p. 290, t. II); y sobre cómo respecto de la piratería "todas las naciones se han creído con derecho para castigar este crimen" (p. 115, t. II). Además, respecto del tráfico de productos nocivos para la salud incluyendo el opio (p. 367, t. II), que hoy en día cabe dentro de las prohibiciones del tráfico ilícito de estupefacientes y sustancias sicotrópicas, la regulación vigente en 1848 castigaba, de manera similar a la actual, no sólo la venta sin la competente autorización de esas sustancias, sino también su "elaboración", "despacho" y "comercio"; así como el despacho y "suministro" autorizados, pero realizados "sin cumplir con las formalidades prescritas en los respectivos reglamentos" (arts. 246 y 247 del Código penal español de 1848).

Finalmente, en cuanto a la criminalidad económica, baste esta cita de Pacheco para demostrar lo poco "moderna" que, en cierto sentido, es su represión: "Una carta falsa leída en la Bolsa, un posta simulado que se haga entrar ostensiblemente para divulgar cierta noticia, un anuncio hábil inserto en un periódico, pueden en determinadas circunstancias causar un trastorno en los precios, que enriquezca y arruine á mil personas. En esto hay delito real y verdadero. Por mas que pocas veces pueda alcanzarse á su autor” (p. 387, t. III). El comentario se refiere al art. 451 del Código español de 1848, que castigaba a "los que esparciendo falsos rumores, ó usando de cualquier otro artificio, consiguieren alterar los precios naturales que resultarían de la libre concurrencia en las mercancías, acciones, rentas públicas ó privadas, ó cualesquiera otras cosas que fueren objeto de contratación".

11 MUÑOZ CONDE, Francisco, "El nuevo Derecho penal autoritario", en: LOSANO / MUÑOZ CONDE, Globalización, cit. nota 5, p. 161-183, p. 162.

12 Una exposición crítica, denunciando el estado de la cuestión en la dogmática alemana puede verse en HASSEMER, Winfried, "Viejo y nuevo derecho penal", en, del mismo: Persona, mundo y responsablidad, Bogotá: Temis 1999, 167 p., p. 15-37, especialmente p.19-29. 
como en los tratados internacionales y la doctrina, de favorecer el establecimiento de sanciones "eficaces, proporcionadas y disuasivas", y el "cumplimiento" de ciertos "objetivos", a saber: i) "la satisfacción de los compromisos internacionales adoptados por Chile"; ii) "el perfeccionamiento de nuestro ordenamiento jurídico, para situarnos al nivel de los países desarrollados"; y iii) el establecimiento de mecanismos que incentiven a las empresas para que "adopten medidas de autorregulación".

Al respecto, el Mensaje efectivamente recoge las actuales tendencias del Derecho comparado e internacional y se plantea objetivos que son en sí mismos valiosos en una política criminal orientada principalmente a la prevención de la comisión de delitos más que al mero castigo de quienes, como personas naturales, los cometen.

Por otra parte, estableciendo una efectiva responsabilidad penal de las personas jurídicas, se cumpliría no sólo con las condiciones que la OCDE estima necesarias para que un país se incorpore a ella como miembro pleno, sino también se posibilitaría el cumplimiento efectivo de las medidas de control de la criminalidad comprendidas en diversos tratados internacionales que Chile ha suscrito y se encuentran vigentes.

En efecto, si sólo tomamos en consideración los "crímenes de derecho internacional" a que hace mención la actual "Estrategia" de la Oficina de las Naciones Unidas sobre Drogas y Crimen las Naciones Unidas, que tienen alguna relevancia para Chile (por ser suscriptor de los tratados concernidos), ${ }^{13}$ a saber, los relativos a drogas, crimen organizado, tráfico de personas, lavado de dinero, corrupción y terrorismo, ${ }^{14}$ veremos que en los tratados respectivos, aparte de las definiciones y los aspectos técnicos relativos a ratificación y vigencia, se establecen alguna

13 Naturalmente, Chile también es suscriptor de diversos tratados que se refieren a temas similares, celebrados en el marco de la Organización de los Estados Americanos, cuyo contenido y alcance no puedo analizar en este lugar, salvo para afirmar que, en lo esencial, las obligaciones que ellos contienen no difieren sustancialmente de las comprendidas en la regulación de las Naciones Unidas, aunque su intensidad es menor. Los principales tratados celebrados en este ámbito regional son: Convención para Prevenir y Sancionar los Actos de Terrorismo Configurados en Delitos Contra las Personas y la Extorsión Conexa Cuando éstos Tengan Trascendencia Internacional, 1971 (suscrita, pero no ratificada por Chile); Convención Interamericana Sobre Extradición de 1981 (suscrita, pero no ratificada por Chile); Convención Interamericana para Prevenir y Sancionar la Tortura de 1985 (ratificada por Chile en 1988); Convención Interamericana Sobre Asistencia Mutua en Materia Penal de 1992 y su Protocolo de 1995 (ratificados por Chile en 2004); Convención Interamericana Sobre Desaparición de Personas de 1994 (suscrita, pero no ratificada por Chile); Convención Interamericana para Prevenir, Sancionar y Erradicar la Violencia Contra la Mujer »Convención De Belem Do Para» de 1994 (ratificada por Chile en 1994); Convención Interamericana Sobre Trafico Internacional de Menores de 1994 (no suscrita por Chile); Convención Interamericana Contra la Corrupción de 1996 (ratificada por Chile en 1998); Convención Interamericana Contra la Fabricación y el Tráfico Ilícitos de Armas de Fuego, Municiones, Explosivos y Otros Materiales Relacionados de 1997 (ratificada por Chile en 2003); y Convención Interamericana Contra el Terrorismo (ratificada por Chile en 2004).

14 Véase la página web de esta oficina: http://www.unodc.org/unodc/index.html [visitada el 26.05.2009]. La "Estrategia" en cuestión comprende actualmente también otros tópicos, como la reforma a los sistemas penitenciarios y de justicia juvenil, como puede verse en el documento alojado en http://daccessdds.un.org/doc/ UNDOC/GEN/V07/806/75/PDF/V0780675.pdf?OpenElement [visitado el 26.05.2009] 
Informe sobre el proyecto de ley que establece la responsabilidad legal de las personas jurídicas en los delitos de lavado de activos, financiamiento del terrorismo y delitos de cohecho que indica, mensaje $\mathrm{N}^{\circ}$ 018-357/

o varias de las siguientes obligaciones internacionales en materia penal:

- Que los Estados Parte tipifiquen determinados delitos, más o menos detalladamente descritos en el tratado, los cuales, siendo de carácter común, pueden tener efectos transnacionales imponiéndoles penas privativas de libertad más o menos graves, ${ }^{15}$

- Que los Estados Parte impongan, además, el más amplio comiso posible de los bienes producto de dichos delitos y de los que los sustituyan; ${ }^{16}$

- Que los Estados Parte establezcan medidas para hacer efectiva la responsabilidad de las personas jurídicas por su participación en dichos delitos $;{ }^{17} \mathrm{y}$

- Que los Estados Parte adopten reglas que favorezcan la delación compensada como eximente ("inmunidad judicial") o atenuante. ${ }^{18}$

Además, una característica del conjunto de estas convenciones y tratados es que, en general sus normas no son "autoejecutables" (self executing), ${ }^{19}$ sino obligaciones internacionales de diferente intensidad, ${ }^{20}$ que en todo caso se encuentran necesitadas de implementación por parte de los Estados suscriptores, ${ }^{21}$ conforme a su propio sistema jurídico. ${ }^{22}$

15 Art. 36 de la Convención Única sobre Estupefacientes de 1961.

16 Art. 5 de la Convención de las Naciones Unidas contra el Tráfico Ilícito de Estupefacientes y Sustancias de 1988.

17 Art. 26 de la Convención de las Naciones Unidas contra la Corrupción de 2003.

18 Art. 3.6. Convención de las Naciones Unidas contra el Tráfico Ilícito de Estupefacientes y Sustancias de 1988.

19 La necesaria distinción entre las normas de un tratado que serían "autoejecutables" y aquellas que por el lenguaje empleado en el tratado o la naturaleza de las obligaciones contraídas, requieren de un acto del poder legislativo de cada Estado parte para tener aplicación directa en los tribunales internos ha sido desarrollada principalmente por la Corte Suprema de los Estados Unidos, en interpretación del art. $6^{\circ}$, inc. $2^{\circ}$ de su Constitución, según el cual la "Constitución y las leyes de los estados Unidos que se expidan con arreglo a ella, y todos los tratados celebrados o que se celebren bajo la autoridad de los Estados Unidos, serán la suprema ley del país y los jueces de cada Estado estarán obligados a observarlos". Al respecto, los fallos donde se sientan las bases de esta doctrina que se ha mantenido inalterada hasta hoy día son Foster v. Neilson. 27 U.S. 253 (1829), y U.S. v. Percheman. 32 U.S. 51 (1833). Una aplicación reciente de la misma, puede verse en el controvertido caso Hamdam v. Rumsfeld, Secretary of Defense et al. 29.06.2006.

20 Según la clasificación de Virally: "invitaciones a observar comportamientos", "obligaciones de desarrollo discrecional", "obligaciones generales no concretadas", y "obligaciones concretas". La determinación del contenido preciso de una norma de derecho internacional queda, por tanto, entregada a la interpretación del lenguaje empleado. Ver al respecto: MATUS A., Jean Pierre; ORELLANA C., Marcos, "Acerca de la existencia de obligaciones internacionales de establecer delitos medioambientales, contempladas en los tratados suscritos por la República de Chile”. Revista de Derecho y Jurisprudencia. t. XCVIII, n 4, 2001, p. 93-113, p. 98-100, donde se encuentran las referencias a los tratadistas de derecho internacional pertinentes.

$21 \quad$ Sobre la necesidad de "implementar" legislativamente las normas del Derecho internacional penal en general (y en particular, las del Estatuto de Roma), junto con una descripción de los para hacerlo, puede verse los textos de CÁRDENAS, Claudia, "Los crímenes del Estatuto de la Corte Penal Internacional en el derecho chileno, necesidad de una implementación". Polít. crim. no 2, A1, 2006, p. 1-17, y NAVARRO D., Roberto, "Los efectos en el sistema chileno de fuentes del Derecho penal de la incorporación de los tratados internacionales y del fenómeno de la globalización”. Ius et Praxis. Año 10, n 1, 2004, p. 77-111.

22 Para ilustrar este aspecto, tomemos como ejemplo la Convención de las Naciones Unidas Contra la Delincuencia Transnacional (Convención de Palermo de 2000, vigente desde el 29 de septiembre de 2003). Según las "Guías Legislativas" preparadas por la UNODC, primero hay que distinguir cuándo el tratado obliga determinadamente, 
Pero, al contrario de lo ocurrido en el Derecho internacional de buena parte del siglo XX, los diversos convenios multilaterales suscritos a fines de éste y a principios del siglo XXI, contemplan mecanismos institucionales o "técnicas organizadas" 23 para garantizar que los Estados Parte implementen sus disposiciones, las cuales permiten controlar la efectiva implementación de sus acuerdos por cada Estado, superponiéndose así a los mecanismos tradicionales de la vigilancia informal del conjunto de la comunidad internacional. Así, por ejemplo, existen tanto "técnicas convencionales", que obligan a que los Estados Parte informen periódicamente de los avances en la materia a alguna autoridad designada (Secretaría General, Conferencia o Asamblea de las Partes, etc.) en el Tratado respectivo para controlar su implementación; ${ }^{24}$ como la "técnica institucional" de encomendar a un organismo internacional la vigilancia y verificación del cumplimiento del Tratado, con base en sus facultades generales, como sucede típicamente con la labor de la UNODC para proveer de asistencia legal (incluyendo la elaboración de legislaciones modelos y guías para su implementación), entrenamiento a legisladores, jueces y fiscales, y asesoría técnica para facilitar la colaboración judicial (traducciones, intermediación, etc.), con el propósito de hacer efectivos los objetivos de las principales convenciones sobre crímenes de trascendencia internacional. ${ }^{25}$

En lo que toca a la materia que nos convoca en particular, también está en lo cierto el Mensaje en cuanto a que en este proceso de implementación no existe una decisión consistente de los Estados en torno a establecer las responsabilidad penal propiamente tal de las personas jurídicas, sino básicamente un sistema de sanciones "eficaces, proporcionales y disuasivas, incluidas sanciones monetarias". ${ }^{26}$

Sin embargo, es más o menos claro que en nuestro ordenamiento esas características no son predicables de las sanciones civiles, cuya finalidad es preeminentemente reparatoria o compensatoria, ni de las administrativas, que por quedar reservadas a organismos cuyas

entrega alternativas de acción o simplemente faculta (insta) a adoptar alguna medida; y en segundo término, si es necesario y cómo sería posible, de acuerdo a las regulaciones internas, modificar la legislación para cumplir con los mínimos y, si se quiere, recoger las invitaciones que hace la comunidad internacional ( $\left.\mathrm{N}^{\mathrm{o}} 8\right)$.

23 En general, sobre los procedimientos jurídicos para hacer cumplir las disposiciones de los tratados, véase COMBACAU /SUR, Droit International, cit. nota 3, p.165-216, y sobre las "técnicas organizadas" de implementación, particularmente, las p. 204-207.

24 Pionera, la Convención Única de 1961 sobre Estupefacientes, que estableció como órganos internacionales de fiscalización de su implementación a la Comisión de Estupefacientes del Consejo Económico y Social y a la Junta Internacional de Fiscalización de Estupefacientes, que existían anteriormente. En los tratados más modernos se utiliza el expediente de la "Conferencia de Partes" como autoridad encargada de supervigilar su implementación, bajo el control indirecto de la Secretaría General (así, los Convenios CITES y la Convención contra la Delincuencia Organizada Transnacional).

25 Véase el brouchure de la UNITED NATIOS OFFICE ON DRUGS AND CRIME, Global programmes. Update november 2003. En http://www.unodc.org/pdf/crime/publications/cicp_global_programmes.pdf [visitado el 14.12.2006].

26 Art. 10 de la Convención contra la Delincuencia Organizada Transnacional de 2000. 
Informe sobre el proyecto de ley que establece la responsabilidad legal de las personas jurídicas en los delitos de lavado de activos, financiamiento del terrorismo y delitos de cohecho que indica, mensaje $\mathrm{N}^{\circ}$ 018-357/

resoluciones no producen el efecto comunicacional de la justicia criminal, difícilmente pueden considerarse suficientemente proporcionales y disuasivas ante los graves hechos de que se trata. Una organización que se estructura de tal manera que favorece o se aprovecha del lavado de dinero, el financiamiento de terrorismo y el cohecho, no puede quedar inmune a las sanciones penales, con independencia de la responsabilidad que les cabe a las personas naturales que toman las decisiones o ejecutan los hechos delictivos. Naturalmente, dado que dichas sanciones afectarán el patrimonio o la organización social, indirectamente ellas repercutirán en el patrimonio de quienes poseen participaciones sociales (en la medida de su participación), pero no han tomado las decisiones ni ejecutado los hechos delictivos, del mismo modo como les repercuten las ganancias y las pérdidas proporcionalmente a su participación, cuando tales decisiones y actividades las producen, pues ellos también son responsables de contribuir a la existencia de la organización.

Por ello, el Mensaje debería derechamente hacerse cargo de estas insuficiencias de la regulación administrativa y civil y, en vez de hablar de la responsabilidad "legal" de las personas jurídicas, debería regular derechamente su responsabilidad "penal”. De eso estamos hablando, ya que la responsabilidad civil y administrativa es también responsabilidad "legal", por lo que recurrir a esta expresión para imponer sanciones en un modelo de prevención del delito lleva a confusión o supone un simple "fraude de etiquetas" destinado, al parecer, para evitar conflictos con la doctrina que por discutibles "razones dogmáticas" considera imposible establecer una "responsabilidad penal de las personas jurídicas", admitiendo únicamente la administrativa o civil. $^{27}$

27 Así todavía en España, a contrapelo de la reforma legislativa en curso que pretende establecer un modelo de imputación de responsabilidad penal de las personas jurídicas similar al propuesto en el Mensaje que informo, puede verse el reciente artículo de ROBLES PLANAS, Ricardo, "Comentario. El "hecho propio" de las personas jurídicas y el Informe del Consejo General del Poder Judicial al Anteproyecto de Reforma del Código Penal de 2008", InDret 2/2009, pp. 1-12. El autor plantea que "la persona jurídica no posee "libertad"” y, por lo tanto, carece de "voluntad" y, en definitiva, de capacidad de "culpabilidad" en el "sentido penal" (p. 6). Es interesante hacer notar que, para llegar a esta conclusión se parte de una petición de principio: sólo las personas naturales pueden "responder" penalmente, las jurídicas, únicamente en el ámbito civil o administrativo, dado que este sería el "sistema de reglas de inculpación y exculpación vigente para afirmar o negar la responsabilidad" (p. 6). Sin embargo, lo que está vigente es sencillamente contingente a las valoraciones sociales del momento y no es un argumento para impedir su modificación, cuanto más si para ello se recurre a la autoridad de quienes, como JAKOBS (nota 8 en p. 6), haciendo caso omiso de su propuesta de reconstrucción puramente "normativa" de la responsabilidad penal y del propio concepto de "persona" (entendido únicamente como "centro de imputación" penal, diferenciable del "sistema psicobiológico" o "ser humano"), de pronto se ven constreñidos por conceptos y "estructuras" ontológicas o pre-legislativas y "resucitan", por así decirlo, la psicología de la "voluntad" y la “autocomprensión” únicamente para defender el prejuicio arraigado en la dogmática alemana de que sólo las "personas físicas" son capaces de culpabilidad; lo que evidentemente no explica cómo es que la Unión Europea compele a sus miembros a establecer "normativamente" la responsabilidad penal de las personas jurídicas, la cual, además, se encuentra plenamente vigente apenas cruzando las fronteras germanas, en Francia, Italia, e Inglaterra, por sólo poner un par de ejemplos. Tampoco es de recibo el argumento de que para "compensar, prevenir y ordenar las relaciones económicas entre agentes que actúan en distintas posiciones" se emplee 
Pero el cómo hacer efectiva esta responsabilidad de las personas jurídicas es algo que los tratados no dilucidan, dejándolo completamente entregado a los "principios jurídicos" de cada Estado parte. ${ }^{28}$

Luego, y ahora desde el punto de vista estricto del Derecho internacional, la cuestión también no parece ser ya el "si" se debe establecer la responsabilidad penal de las personas jurídicas, sino el "cómo" hacerlo en el marco de nuestro Estado de Derecho, teniendo en cuenta lo que, a la hora de implementar disposiciones emanadas del Derecho Internacional, como señalan las indicaciones generales de las Guías Legislativas elaboradas por la UNODC para la implementación de la Convención contra la Delincuencia Organizada Transnacional de 2000:

“13. Se recomienda que los legisladores verifiquen la coherencia con otros delitos, definiciones y usos legislativos antes de emplear las formulaciones o la terminología de la Convención. La Convención se redactó con fines generales y va dirigida a los gobiernos nacionales. Por consiguiente, su nivel de abstracción es mayor que el necesario para la legislación interna. De ahí que los legisladores deban tener cuidado de no incorporar literalmente partes del texto. En lugar de ello, se les anima a que capten el espíritu y significado de los distintos artículos..."

Insistiéndose después en que

“43. Los legisladores nacionales deberán concentrarse en la sustancia y el espíritu de la Convención, y no intentar traducir simplemente su texto o incluirlo

únicamente el derecho civil o administrativo como algo dado por la naturaleza: todo el derecho penal económico, ambiental, y el viejo penal liberal de las infracciones al comercio, las alteraciones de precios, la revelación de secretos de fábrica, las falsedades y las estafas está ahí, entre otras cosas, para "compensar, prevenir y ordenar las relaciones económicas entre agentes que actúan en distintas posiciones" (otra cosa es que se crea que el derecho penal es únicamente retributivo, con lo cual entraríamos a preguntarnos por qué se han de destinar recursos escasos únicamente para satisfacer la ya denunciada por Platón como "irracional venganza"). Con todo, la discusión no pasa en muchos momentos de ser puramente semántica, pues los autores que rechazan la posibilidad de la responsabilidad penal de las personas jurídicas, por "razones dogmáticas", no rechazan la de que las personas jurídicas "respondan" jurídicamente ni la clase de sanciones establecidas para ello, sino, únicamente, parece que se quiere que no se denomine "responsabilidad penal", como antes, en sentido similar, afirmara MIR PUIG, Santiago, "Una tercera vía en materia de responsabilidad penal de las personas jurídicas". Revista electrónica de ciencia Penal y Criminología. 06-01, 2004, quien afirma, refiriéndose a las "consecuencias accesorias" del art. 129 del Código Penal español de 1995 : "no hay duda de que la voluntad del legislador expresada en la ley ha sido la de salir al paso del peligro que pueden representar las personas jurídicas y empresas utilizadas para la comisión de delitos, sin cuestionar el principio de que el delito es únicamente un hecho humano" (p. 3).

28 Para la discusión en nuestro ámbito cultural, véase la recopilación de trabajos de Jakobs, Silva Sánchez, Seelman, S. Bacigalupo, Feijoo Sánchez, Gómez-Jara, Mazuelos y García Cavero, contenidas en el volumen de GARCÍA CAVERO, Percy (coordinador), La responsabilidad penal de las personas jurídicas, órganos y representantes. Lima: Ara 2002, 502 p. 
Informe sobre el proyecto de ley que establece la responsabilidad legal de las personas jurídicas en los delitos de lavado de activos, financiamiento del terrorismo y delitos de cohecho que indica, mensaje $\mathrm{N}^{\circ}$ 018-357/

literalmente en nuevas leyes o enmiendas. La redacción de leyes sobre nuevos delitos y su aplicación, incluidos los medios jurídicos de defensa y demás principios jurídicos, quedan reservadas a los Estados Parte (...). Por consiguiente, los legisladores deben cerciorarse de que los nuevos artículos estén en consonancia con la tradición jurídica, los principios y las leyes fundamentales del propio país. Así se evitará el riesgo de conflictos e incertidumbre acerca de la interpretación de las nuevas disposiciones por parte de los tribunales o los jueces".

\section{El contenido del Mensaje. Propuestas de perfeccionamiento}

\subsection{Necesidad de la aprobación en general del sistema adoptado por el Mensaje para establecer la responsabilidad penal de las personas jurídicas: la prevención de los delitos mediante los “modelos de organización” o programas éticos}

El Mensaje recoge un sistema de responsabilidad penal de las personas jurídicas que responde a las actuales tendencias del derecho norteamericano y europeo, particularmente, del italiano, centrado en obtener la colaboración de las empresas en las labores de prevención del delito, mediante el establecimiento de lo que denomina "modelos de organización, administración y supervisión", cuya efectiva implementación debería ser suficiente para que las personas jurídicas no se vean expuestas a sanciones de carácter penal.

Este es un sistema que no atribuye directamente responsabilidad penal a las personas jurídicas por los delitos cometidos por personas naturales a su servicio ("sistema vicarial"); ni asume la creencia de que ellas se gobiernan con total autonomía de las personas naturales que tomas decisiones y las ejecutan ("sistema de culpabilidad de la empresa"); sino establece las condiciones en las cuales, de cometerse un delito, la persona jurídica interesada en su realización ha de responder penalmente, esto es, con sanciones efectivas, proporcionales y disuasivas. Y esas condiciones son, básicamente, la atribución de obligaciones de supervisión y dirección en orden a la prevención de las actividades delictivas y, por lo tanto, de implementación de modelos o programas de prevención, cuya ausencia o defectuosa implementación permite la imposición de sanciones de carácter penal a las personas jurídicas. Por lo mismo, puede caracterizarse como un "sistema de determinación de la pena" o "mixto". ${ }^{29}$

29 Para una visión general de los diferentes modelos legislativos arriba resumidos, véase NIETO, Adán, La responsabilidad penal de las personas jurídicas: un modelo legislativo, Madrid: Iustel, 2008, pp. 85-214. 
Luego, el aspecto principal de esta forma de abordar el problema es la extensión de los conocidos programas de responsabilidad social de la empresa ${ }^{30}$ a la prevención de los delitos que pueden favorecer las formas de organización actuales - muchas veces organizadas en función únicamente de la obtención de resultados, sin atención a los medios empleados-, ${ }^{31}$ pero que no son necesarias ni propias de la actividad empresarial, ni mucho menos un "mal" que se deba "tolerar" para obtener buenos resultados. Estos programas de responsabilidad social ya existen en muchas empresas nacionales y, en lo que respecta a los programas éticos de prevención de delitos, son impuestos por la regulación norteamericana a todos los empleados de las más importantes empresas multinacionales que operan en nuestro país, como, por citar un caso muy conocido, The Coca-Cola Company. ${ }^{32}$

Al respecto, el Mensaje establece no sólo la imposibilidad de perseguir criminalmente a una empresa que haya "adoptado e implementado eficientemente modelos de organización, administración y supervisión para prevenir delitos" (art. $3^{\circ}$, inc. final); sino que, además, facilita la adopción de tales "modelos" mediante la dictación de un Reglamento que determine sus aspectos básicos $\left(\operatorname{art.} 4^{\circ}\right)$.

Luego, sin perjuicio de las propuestas de perfeccionamiento que enseguida paso a detallar, debe considerarse este sistema de atribución de responsabilidad, que permite eximirse de la misma mediante la adopción e implementación efectiva de "modelos de organización" o planes de prevención, el núcleo de la propuesta del Ejecutivo y la mayor fortaleza de la misma. En efecto, ella permite al mismo tiempo, por una parte, responsabilizar a las organizaciones empresariales en la prevención del delito; y por otra, reservar las medidas penales como auténtica ultima ratio, sólo para aquellas organizaciones que no están dispuestas a colaborar en esta tarea común, o que sólo "aparentan" colaborar con ella, mediante la adopción formal de documentos escritos, sin su implementación efectiva.

\subsection{Los perfeccionamientos necesarios para la normativa propuesta}

Asumiendo la adopción del sistema de imputación de responsabilidad penal de las personas

$30 \quad$ Véase al respecto las informaciones disponibles en BALTERA, Pablo y DÍAZ, Estrella, "Responsabilidad social empresarial: Alcances y Potencialidades en Materia Laboral”, Cuaderno de Investigación $N^{o} 25$ (División de Estudios de la Dirección del Trabajo de Chile), 2005.

$31 \quad$ El carácter "estructural" del delito de empresa, favorecido directa e indirectamente por determinadas prácticas y formas de organización (división del trabajo, compartimentabilización de la información, subordinación y jerarquía, etc.) cuando se omite todo control ético o legal del actuar de los miembros de la empresa, se encuentra suficientemente documentado en la experiencia internacional, como puede verse en NIETO, La responsabilidad penal, cit. en nota 29, pp. 38 a 42, con numerosas referencias bibliográficas a autores alemanes, españoles y norteamericanos.

32 El Programa en español de The Coca Cola Company puede verse en http://www.thecoca-colacompany.com/ ourcompany/pdf/COBC Spanish.pdf [visitado el 27.05.2009]. 
Informe sobre el proyecto de ley que establece la responsabilidad legal de las personas jurídicas en los delitos de lavado de activos, financiamiento del terrorismo y delitos de cohecho que indica, mensaje $\mathrm{N}^{\circ}$ 018-357/

jurídicas previsto en el Mensaje, restan todavía algunos detalles técnicos en la redacción del mismo que deben ser perfeccionados.

Al respecto, para facilitar la inteligencia de mis observaciones, utilizaremos el mismo orden que emplea el Proyecto contenido en el Mensaje informado:

Art. $1^{\circ}$

a) Debería sustituirse la expresión "responsabilidad legal" por "responsabilidad penal", que es lo que realmente se está estableciendo;

b) En cuanto al alcance, debería extenderse, aparte de los hechos que allí se mencionan, a los siguientes:

i) Todos los del Tit. IV, L. II Código penal (falsificaciones).

Justificación: Estos son quizás los delitos más comunes en el ámbito empresarial y que se utilizan para cometer diversas infracciones;

ii) Del Tit. VI, L. II Código penal, los comprendidos en los párrafos 3 (rotura de sellos), 4 (embarazos puestos a la ejecución de trabajos públicos), 5 (crímenes y simples delitos de los proveedores), 6 (loterías y juegos prohibidos), 7 (relativos a la industria, al comercio y las subastas públicas), 9 (salud animal y vegetal), 10 (asociaciones ilícitas) y 14 (salud pública):

Justificación: Todos estos delitos regulan la actividad económica que hoy se realiza empresarialmente y el párrafo 10 una forma especial de organización que, cuando se manifiesta bajo la fachada de una personas jurídica, debe ser severamente reprimida.

iii) Del Tit. IX, L. II Código penal, los comprendidos en los párrafos 5bis (receptación), 6 (usurpación de tierras y aguas) y 10 (daños):

Justificación: Se trata de delitos «comunes», pero cuyos resultados -apropiación de tierras, aguas y destrucción de bienes de la competencia- favorecen determinadas actividades económicas frente a otras;

iv) Los cuasidelitos del Tit. X, L. II Código Penal y los delitos comprendidos en la Ley de Tránsito:

Justificación: Esta es la fuente de responsabilidad empresarial más habitual hoy en día, a través del Derecho Civil, pero al mismo tiempo ineficiente para asegurar la vida y salud de los trabajadores y de la población en general, como sucede en los casos de construcciones o productos defectuosos y de responsabilidad en el transporte, donde la organización empresarial puede ayudar a prevenirlos o, por el contrario, a fomentarlos indirectamente mediante turnos extenuantes, falta de control en contrataciones y prestación de servicios, etc. 
v) Los delitos ecológicos y de contaminación comprendidos en los Arts. 135 a 139 del Código de Aguas, 138 de la Ley General de Urbanismo y 38 de la Ley de Monumentos Nacionales, y arts. 30 y 31 de la Ley de Caza.

Justificación: Los delitos ecológicos y de contaminación de aguas se encuentran comprendidos en diversos tratados internacionales que, al igual que las convenciones de la OCDE, exigen el establecimiento de sanciones "eficaces, disuasivas y proporcionales" a las personas jurídicas.

vi) Los comprendidos en la Ley Antimonopolios (y su reforma en proyecto), y en las leyes de Bancos, AFP, Valores y Seguros:

Justificación: Se trata de ámbitos en los cuales la experiencia reciente ha demostrado la insuficiencia de los mecanismos administrativos para la sanción efectiva, disuasiva y proporcional de los hechos que pueden cometerse (caso farmacias); o en los cuales sólo es posible la participación en el mercado (AFP, Bancos, Seguros, Sociedades de Valores) de personas jurídicas.

vii) Los comprendidos en el Código Tributario:

Justificación: Sobra señalar no sólo la necesidad de prevenir la comisión de esta clase de delitos para el adecuado funcionamiento del Estado, sino también la de establecer expresamente la responsabilidad penal de las personas jurídicas en este ámbito, de manera que la sanción de las infracciones tributarias punibles no recaigan únicamente en personas naturales, que no se aprovechan de la comisión de tales hechos.

viii) Las infracciones punibles relativas a los derechos de los trabajadores y la seguridad social, especialmente las referidas al no pago de cotizaciones previsionales:

Justificación: La necesidad de prevenir la creación de "lagunas previsionales" es indiscutible y del interés de la sociedad toda y, por lo mismo, no puede esperarse a la quiebra de las empresas o a los finiquitos masivos de trabajadores para su descubrimiento. Un sistema de prevención de esta clase de delitos, establecido a través de los mecanismos que provee este Proyecto de Ley, es esencial para mantener un sano sistema de seguridad social.

Art. $3^{\circ}$

Debería sustituirse por el siguiente:

«Artículo $3^{\circ}$.- Atribución de responsabilidad penal. Las personas jurídicas serán penalmente responsables de los delitos señalados en el artículo $1^{\circ}$ cometidos por personas naturales en la decisión o realización de las actividades total o parcialmente financiadas por aquéllas o que, directa o indirectamente, les produzcan ingresos o disminuyan sus costos, siempre que la comisión del delito se haga posible por la falta de implementación efectiva al 
Informe sobre el proyecto de ley que establece la responsabilidad legal de las personas jurídicas en los delitos de lavado de activos, financiamiento del terrorismo y delitos de cohecho que indica, mensaje $\mathrm{N}^{\circ}$ 018-357/

interior de la organización de modelos de prevención de delitos adecuados a su naturaleza, tamaño y actividades.

No se entenderá como implementación efectiva de un programa o modelo de prevención su sola formulación o la adopción de uno formulado por la autoridad, si ellos no suponen implementar procedimientos y resguardos que hagan efectiva la posibilidad de denunciar las actividades sospechosas sin riesgo de pérdida del empleo ante un responsable de la organización o un tercero designado para ello.

La responsabilidad penal de las personas jurídicas se hará extensiva también a las que sean controladoras, de hecho o de derecho, de las responsables conforme a las disposiciones anteriores, así como a aquéllas que establezcan franquicias u otros sistemas de comercialización que utilicen una misma marca o individualización genérica frente al público.»

Justificación: En el Proyecto informado el art. 3 utiliza la expresión, que denota un elemento subjetivo, de actuar "en su interés o para su provecho"; y establece una disposición redundante en el inciso final que emplea otra expresión subjetiva, esto es cometer el delito "exclusivamente en ventaja propia etc."

Sin embargo, un adecuado sistema de responsabilidad penal de las personas jurídicas debería eliminar las referencias subjetivas y, particularmente, elementos subjetivos, que terminen vinculando la responsabilidad de la persona jurídica directamente a la de una persona natural, pues se trata de hacer de cada una de estas responsabilidades algo independiente. En efecto, debe tenerse en cuenta que, por una parte, en organizaciones complejas, muchas veces será difícil determinar quién es el verdadero responsable de una decisión o de su ejecución y cuáles serían sus motivaciones subjetivas. Por otra, la presencia de estos elementos subjetivos, de difícil prueba (se requiere, en la práctica, que una persona natural sea sentada a declarar y «confiese» su intencionalidad), hacen muy difícil la atribución de responsabilidad en los casos frecuentes de omisión de controles, antes negligentes que intencionales.

Por lo tanto, para que la prevención sea efectiva y se pueda separar la responsabilidad de las personas naturales que intervienen de la de las personas jurídicas, es necesario objetivizar la atribución de responsabilidad, no vinculándola a intenciones o cualquier otra cosa que parezca subjetiva, tanto para imputarles responsabilidad como para eximirlas de la misma, ya que eso haría que su responsabilidad dependiera no de la implementación objetiva de los modelos de prevención, sino de las intenciones de las personas naturales que actúan.

Por otra parte, el Proyecto no da cuenta de la responsabilidad que cabe a las personas jurídicas que se organizan en grupos de empresas y frente a sus subsidiarias o franquiciadas. Es por ello que debe extenderse la responsabilidad de las personas jurídicas a las que sean controladoras de otras, para evitar la creación de sociedades de papel que sirvan únicamente de "chivo expiatorio". 


\section{Art. $4^{\circ}$}

Como se dijo, este artículo es esencial en el sistema adoptado por el Proyecto, al establecer las bases de los modelos de administración (programas éticos) que, de implementarse efectivamente, permitirían eximir de responsabilidad penal a las personas jurídicas.

Sin embargo, el rasgo distintivo de tales modelos o programas éticos -el establecimiento de mecanismos de denuncia y fiscalización internos a cargo de "responsables de prevención" independientes de los administradores y con facultades para denunciar ante la autoridad públicano está mencionado y debería aparecer explícitamente en la ley, para evitar la adopción meramente formal de reglamentos internos. Estos "responsables de los programas de prevención" ("guardianes" o gatekeepers) deberían no sólo ser independientes de la administración, sino también informar periódicamente a la autoridad acerca de las medidas y planes implementados y, eventualmente, personalmente responsables de la no evitación de los delitos cuyos indicios conozcan o de la omisión de su denuncia, cuando ya se hayan cometido.

Por lo tanto, propongo agregar los siguientes dos incisos a la redacción del art. $4^{\mathrm{o}}$ :

\section{“Art. $4^{0} \ldots$}

Los responsables de la implementación de los modelos de prevención deberán emitir semestralmente un informe acerca de las medidas adoptadas por la persona jurídica y las actividades de prevención en las que ha participado, una copia del cual se depositará en sobre cerrado en una Notaría de la comuna del domicilio social de la persona jurídica, con instrucciones de apertura y facilitación de copia a requerimiento del Ministerio Público, la Unidad de Análisis Financiero, el Servicio de Impuestos Internos, la Superintendencia de Valores y Seguros o los Tribunales con competencia en lo criminal, en su caso.

Los responsables de la implementación de los modelos de prevención se considerarán personalmente responsables de la comisión de algún delito de los mencionados en el art. $1^{\circ}$, respondiendo en calidad de autores de los mismos conforme a lo dispuesto en los artículos 14 y 50 del Código Penal, si han recibido denuncias o noticias de las actividades preparatorias del mismo o de la decisión de cometerlo, y no han realizado ante los representantes y administradores de la persona jurídica las gestiones relevantes para evitar que se continúen realizando dichas actividades o se ejecute la decisión denunciada. La misma pena se les impondrá si, realizadas dichas gestiones, los representantes y administradores de la persona jurídica persisten en la realización o ejecución de las actividades o decisiones denunciadas, y los responsables de la implementación de los modelos de prevención no los denuncia ante la autoridad.

En caso de que el responsable reciba noticias o denuncias de un delito ya cometido, deberá denunciarlo a la autoridad. La omisión de esta denuncia se castigará con la pena 
Informe sobre el proyecto de ley que establece la responsabilidad legal de las personas jurídicas en los delitos de lavado de activos, financiamiento del terrorismo y delitos de cohecho que indica, mensaje $\mathrm{N}^{\circ}$ 018-357/

correspondiente a la del encubridor del delito cometido.

Los responsables de la implementación de los modelos de prevención sancionados por alguno de los delitos descritos en los incisos anteriores, sufrirán además la pena accesoria de inhabilitación absoluta perpetua para ejercer las mismas o análogas funciones, así como para ser socio o tener una participación mayor al 5\% de una sociedad de personas o anónima, respectivamente, que ofrezca a otras personas jurídicas similares servicios.»

Art. $5^{\circ}$

Propongo sustituirlo por el siguiente:

«Artículo $5^{\circ}$. Responsabilidad penal autónoma de las personas jurídicas. La responsabilidad penal de las personas jurídicas es independiente de la responsabilidad personal que, en conformidad con las reglas generales, corresponde a quienes cometan delitos ejerciendo, de hecho o de derecho, labores de administración, supervisión y representación de la misma; así como de la que corresponde a las personas naturales que, sin ejercer dichas labores, cometan delitos actuando por cuenta o bajo dependencia de la persona jurídica.»

Justificación: La actual redacción tiende a confundir la responsabilidad penal de las personas jurídicas con la de las personas naturales que actúan, con lo que se producen eventuales problemas de bis in idem, los cuales se pueden superar aclarando la autonomía y el diferente fundamento de la responsabilidad en cada caso.

\section{Encabezado del $§ 2$ y Art. $6^{\circ}$}

Propongo su sustitución por los siguientes:

\section{$\S 2$. Responsabilidad penal de las pequeñas y medianas empresas}

Artículo 6. Pequeñas y medianas empresas. Las personas jurídicas que empleen a menos de 50 personas, cualquiera sea su régimen contractual, podrán solicitar la suspensión condicional del procedimiento, estableciéndose como condición para ello la supervisión judicial de la administración, a costa de la persona jurídica, con la sola finalidad de diseñar e implementar un modelo de prevención de delitos efectivo. La supervisión se encargará personalmente a un abogado, contador u otro profesional universitario, quien informará de sus gestiones al tribunal y estará sometido a las mismas responsabilidades señaladas en el artículo $4^{\circ}$ para los responsables de los programas de prevención.

En caso que la persona jurídica sea franquiciada, subsidiaria o controlada de o por otra persona jurídica, ésta soportará el costo de la supervisión judicial, sin perjuicio de la responsabilidad penal que le corresponda, en virtud de lo dispuesto en el artículo $3^{\circ}$." 
Justificación: No parece apropiado hablar, como hace el Proyecto, de que están "exentas" de responsabilidad penal ciertas organizaciones que calificaríamos como "pequeñas y medianas empresas" o que están constituidas únicamente como "fachadas" para cometer delitos. ${ }^{33}$

En el primero de los casos, basta con un procedimiento especial para poder discernir si se trata realmente de una "PYME" o es más bien una sociedad subordinada o controlada por otra mayor; y en caso de ser una "PYME" auténtica, proceder facultativamente con suspensiones condicionales del procedimiento que no impliquen su ruina.

Y en el segundo, con establecer para estos casos, dentro del párrafo referido a las penas, la sanción única la disolución de la persona jurídica. Un prurito "dogmático" no debe conducirnos a señalar al mismo tiempo que la persona jurídica está "exenta" de responsabilidad, pero que de todas maneras debe ser disuelta, lo que, si bien puede ser explicable entre especialistas, constituye un extraño mensaje para la comunidad, pues se dice que las personas jurídicas de derecho privado y las empresas públicas creadas por ley son responsables penalmente, a menos que estén constituidas con el único propósito de cometer delitos. Por lo demás, no debe dejar de considerarse que una cosa es el propósito con que se constituye una persona jurídica y otra lo que ésta va realizando en su vida jurídica, siendo no improbable que, como sucede con empresas de servicios que sirven de fachada para el "lavado de dinero", presten tanto servicios lícitos como ilícitos. Finalmente, también es reprobable que se mezcle la responsabilidad de las personas jurídicas con la "finalidad" de quienes las constituyen, si se ha señalado que tanto unas como otras responden de manera autónoma.

\section{Encabezados del Título II y sus párrafos}

En conformidad con lo antes señalado, este Título debería tratar derechamente de las "Consecuencias de la declaración de responsabilidad penal de las personas jurídicas"; "de las penas en general" (§ 1); "de la determinación de las penas" (§ 2); y "del quebrantamiento y de la extinción de la responsabilidad penal de la persona jurídica".

\section{Artículo $9^{\circ}$}

El artículo debería denominarse "penas" y las expresiones "sanciones prohibitorias" y "sanciones consistentes en pérdidas de beneficios", reemplazarse por "paralización parcial de actividades o prohibición de realizar actividades determinadas" y "pérdida perpetua total y temporal de beneficios fiscales", respectivamente; dada la inexistencia de la expresión

\footnotetext{
33 El modelo en el cual parece inspirarse el Proyecto, propuesto por NIETO, La responsabilidad penal de las personas jurídicas, cit. nota al pie 29 , pp. 324 , art. $2^{\circ}$, números 3 y 4 , es igualmente equívoco, al hablar de que en estos casos "no existe responsabilidad".
} 
Informe sobre el proyecto de ley que establece la responsabilidad legal de las personas jurídicas en los delitos de lavado de activos, financiamiento del terrorismo y delitos de cohecho que indica, mensaje $\mathrm{N}^{\circ}$ 018-357/

“prohibitoria” en el castellano y la poca necesidad que existe de darle un nombre diferente a penas que ya tienen el suyo propio en el Proyecto.

\section{Artículos 11 y 12}

No parece apropiado hablar de "escalas" penales cuando lo que se hace es sencillamente describir las penas de que tratan.

\section{Artículo 13}

Propongo su sustitución por el siguiente:

«Artículo 13.- Multa. Multa a beneficio fiscal por la cantidad que sea mayor de cualquiera de las siguientes:

a) El 30\% del capital social, determinado conforme al último balance anual presentado, tratándose de crímenes, y el 20\%, tratándose de simples delitos;

b) El 30\% de los ingresos declarados en la última declaración de renta anual presentada, y el $20 \%$, tratándose de simples delitos;

c) El triple del valor del daño causado, cuando éste sea determinable pericialmente;

En caso que ninguna de esas cantidades sea superior a 200 unidades tributarias mensuales, se impondrá ésta como multa.

El pago de la multa podrá ser fraccionado hasta el período de dos años, cuando su cuantía ponga probadamente en peligro la existencia de la persona jurídica, la estabilidad de los puestos de trabajo existentes en la misma, o cuando lo aconseje el interés social.

En todo caso, los gastos efectivos realizados para reparar el daño causado, hasta antes de la dictación de la sentencia condenatoria, se imputarán al pago de la multa en la liquidación que de ella se haga.

El Tribunal correspondiente, una vez que se encuentre ejecutoriada la sentencia condenatoria, comunicará la aplicación de la multa a la Tesorería General de la República, quien se hará cargo de su cobro y pago."

Justificación: La multa es la pena por excelencia respecto de las personas jurídicas y, como señalan todos los convenios internacionales, debe ser lo suficientemente eficaz, disuasiva y proporcionada a la gravedad de los hechos. Esto significa que su costo no pueda traspasarse sencillamente a los precios de los bienes y servicios que la persona jurídica ofrezca al público ni considerarse un ítem irrelevante en los gastos de operación. Al mismo tiempo, su imposición debe favorecer la reparación del daño causado, cuando se produzca, y permitir la adecuada distinción entre delitos de diversas gravedad, sea en su calificación jurídica (crímenes o simples delitos, sea en su dañosidad social concreta). 
La multa, además, debe ser independiente del comiso de los ingresos percibidos producto del delito, pues se trata de cosas distintas: desde luego, no es posible el comiso cuando el delito no genera "ingresos", sino sólo gastos (como sucede en el financiamiento del terrorismo) o la disminución de los gastos en que se incurriría de evitarse efectivamente su comisión (como en los delitos ambientales). Y en segundo término, el comiso sólo alcanza a la privación de ciertos bienes cuya cuantía puede ser perfectamente costeable (una "inversión riesgosa", similar a una en bolsa), lo que no sucede cuando junto a él se impone una multa verdaderamente disuasiva.

\section{Artículo 14}

Propongo la sustitución de la definición del "comiso" por una más amplia, que permita un adecuado juego con la de multa:

\section{"Artículo 14.}

b) Comiso. El comiso de los ingresos obtenidos producto del delito y demás efectos, objetos, documentos e instrumentos del mismo, según lo dispone el Código Penal. En los casos que el delito cometido suponga gastos de recursos de la persona jurídica superiores, se impondrá como pena accesoria, junto al comiso de los ingresos si los hubiese, el reintegro de una cantidad equivalente a los gastos realizados.»

Justificación: Al reemplazar "ganancias" por “ingresos", se pretende no sólo evitar una discusión contable acerca de lo que debe entenderse por ganancias (ingresos obtenidos menos gastos para obtenerlos), sino también no considerar a la actividad delictiva como una suerte de "inversión" de bajo riesgo, limitada exclusivamente por las "ganancias" que se obtengan. La redacción actual parece permitir cometer delitos, sin mayor costo, siempre que uno "renuncie" a las "ganancias", es decir, sin siquiera perder lo "invertido" en ello, con lo cual el riesgo es mucho menor que en cualquier actividad económica normal.

Por lo mismo, se propone, además, que en todo caso se deba pagar como pena accesoria el costo de la "inversión" o "gastos" realizados para delinquir, particularmente necesaria en los casos de delitos que sólo generan "gastos" contables o reducciones en éstos, pero no ingresos directamente relacionados.

\section{Artículo 15}

Se propone simplificar el sistema y hacerlo compatible con la clasificación general de crímenes y simples delitos (el requisito de la "proporcionalidad"), independizando la Escala correspondiente de las penas eventualmente impuestas a las personas naturales. De este modo, su redacción quedaría como sigue: 
Informe sobre el proyecto de ley que establece la responsabilidad legal de las personas jurídicas en los delitos de lavado de activos, financiamiento del terrorismo y delitos de cohecho que indica, mensaje $\mathrm{N}^{\circ}$ 018-357/

\section{"Artículo 15. Escala general.}

Las penas que pueden imponerse con arreglo a esta ley y las restantes que establezcan la responsabilidad penal de las personas jurídicas por crímenes y simples delitos, son las que comprende la siguiente

\section{ESCALA GENERAL DE PENAS PARA PERSONAS JURÍDICAS}

Penas de crímenes

Multa.

Disolución de la persona jurídica o cancelación de las personalidad jurídica.

Paralización parcial de la actividad de la empresa.

Pérdida perpetua y total de beneficios fiscales.

Publicación del fallo.

Comiso.

Penas de simples delitos

Multa.

Prohibición de realizar actividades u operaciones mercantiles

Pérdida temporal de beneficios fiscales.

Publicación del fallo.

Comiso.

Sin perjuicio de lo anterior, en los casos previstos en los artículos 251 bis A y 251 bis B del Código penal, así como en los otros delitos cuya comisión o efectos trasciendan las fronteras de la República, podrán imponerse siempre a los simples delitos penas de crímenes, incluida la disolución o cancelación de la personalidad jurídica, cuando corresponda.

En todo caso, se impondrá siempre la disolución o cancelación de la personalidad jurídica si entre sus actividades principales se encuentra la comisión de alguno de los crímenes o simples delitos sancionados por esta ley, aunque realice algunas actividades lícitas para su ocultamiento.

\section{Artículo 16}

Aquí se debería agregar, como letra "f)", la concurrencia de circunstancias atenuantes o agravantes de la responsabilidad penal, sin una rígida valoración, que no parece compatible con su escaso número.

\section{“Art. 16 ...}

f) el número, naturaleza y cuantía de las circunstancias modificatorias de la responsabilidad que concurran." 


\section{Artículos 20 y 21}

Para evitar confusiones e inesperados privilegios, la prescripción de la acción penal y de la pena debería seguir las mismas reglas generales. Por lo tanto, propongo refundir ambas disposiciones en una sola:

“Artículo 20.- Extinción de la responsabilidad penal. La responsabilidad penal de la persona jurídica se extingue por las mismas razones y en los mismos términos señalados en el artículo 93 del Código penal, salvo su número $1^{\circ}$."

Es todo cuanto puedo a Ud. informar, 


\title{
INFORME SOBRE RESTABLECIMIENTO DE LA PENA DE MUERTE POR PROYECTO DE LEY (BOLETIN N 6642-07)
}

\author{
Humberto Nogueira Alcalá*
}

La Comisión de Constitución; Legislación y Justicia de la Cámara de Diputados me ha solicitado informe sobre la moción presentada que modifica el Código Penal y restituye en casos calificados la pena de muerte (Boletín $N^{\circ}$ 6642-07).

De acuerdo con el proyecto de ley planteado, se restablece la pena de muerte para delitos respecto de los cuales dicha pena ha sido eliminada por la ley $\mathrm{N}^{\circ} 19.734$, por medio del proyecto de ley consignado en el Boletín $N^{\circ}$ 6642-07, que introduce modificaciones al Código penal, en sus artículos 59 y 82 a 85.

El proyecto tiene un fundamento y argumentos que serán objeto de análisis jurídico constitucional en el presente informe.

El fundamento del proyecto afirma correctamente que la pena de muerte no ha sido abolida en Chile, ella subsiste para delitos establecidos en el Código de Justicia Militar en tiempo de guerra y se mantiene la norma constitucional del artículo $19 \mathrm{~N}^{\circ} 1$, inciso $3^{\circ}$, la que posibilita establecer por ley de quórum calificado la pena de muerte.

\section{La delimitación y configuración del derecho a la vida en nuestro ordenamiento jurídico.}

La Convención Americana de Derechos Humanos (CADH) en su artículo 4, asegura el derecho a la vida de las personas y el derecho a la vida del que está por nacer, generalmente, desde la concepción. El derecho a la vida en sus atributos asegurados y garantizados en dicha Convención Internacional de Derechos Humanos que constituyen derechos esenciales

* Doctor en Derecho por la Universidad Católica de Lovaina la Nueva, Bélgica. Profesor Titular de Derecho Constitucional y Director del Centro de Estudios Constitucionales de Chile, de la Universidad de Talca. Presidente de la Asociación Chilena de Derecho Constitucional y Vicepresidente del Instituto Iberoamericano de Derecho Procesal Constitucional. Correo electrónico: nogueira@utalca.cl. 
enriquecen los atributos del derecho a la vida asegurados por el artículo 19 de la Constitución, en el caso en análisis, todo ello de acuerdo al principio básico de interpretación constitucional favor persona o pro homine y al principio de progresividad, de acuerdo a la jurisprudencia tanto de nuestro Tribunal Constitucional, como de la Corte Interamericana de Derechos Humanos.

Así los atributos del derecho a la vida asegurados por la Constitución como los contenidos en la Convención Americana sobre Derechos Humanos constituyen atributos que emanan de la dignidad humana y constituyen derechos esenciales, los cuales, de acuerdo a lo que determina imperativamente el artículo $5^{\circ}$ inciso $2^{\circ}$ de la Constitución, limitan el ejercicio de la soberanía, por tanto, la potestad legislativa ejercida por los órganos colegisladores del Estado Chileno. Por tanto una disposición legal que actuara en tales términos sería inconstitucional, además de vulnerar un derecho humano esencial en los términos que el Estado de Chile, libre y voluntariamente se ha comprometido a respetar y promover, como dispone el mismo inciso $2^{\circ}$ del artículo $5^{\circ}$ de la Constitución. Cabe señalar, por tanto, que dichos atributos constituyen parte del parámetro de control de constitucionalidad, como ya fue utilizada la Convención sobre Derechos del Niño por el Tribunal Constitucional en su sentencia sobre "responsabilidad penal adolescente" (Rol N 786-2007, de fecha trece de junio de 2007) y en el caso de la "Píldora del día después", se aplica el mismo artículo $4^{\circ}$ de la Convención Americana sobre Derechos Humanos (sentencia Rol N 740-07, de fecha 18 de abril de 2008).

El aseguramiento del derecho a la vida en nuestro ordenamiento jurídico ha integrado el contenido mínimo asegurado por el artículo $4^{\circ}$ de la CADH, cuyo párrafo $2^{\circ}$ asegura en su parte final que "No se extenderá la aplicación de la pena de muerte a delitos a los cuales no se la aplica actualmente".

Esta disposición junto con ser parte de la CADH y del derecho internacional, es parte de nuestro ordenamiento jurídico y de aplicación preferente respecto de los preceptos legales internos, debiendo ser interpretada y aplicada de acuerdo con el objeto y fin de protección de los derechos a que se obligó el Estado de Chile de buena fe al incorporar tal disposición de aseguramiento y garantía del derecho a la vida. Así, el artículo 4.2 de la CADH establece un límite definitivo a la pena de muerte para todos los delitos que actualmente no contempla nuestro ordenamiento jurídico, prohibiendo la extensión de su uso hacia el futuro. Sobre ello ya se pronunció y dictaminó la Corte Interamericana en su Opinión Consultiva 3/83 de 8 de septiembre de 1983.

El Derecho Internacional de los Derechos Humanos es fuente del Derecho Interno cuando contiene elementos que enriquecen al Derecho Interno, cuando agregan un "plus" al contenido normativo de los derechos fundamentales delimitados y configurados en el derecho interno y viceversa, el sistema nacional de derecho enriquece al derecho Internacional de derechos humanos, buscando siempre la integralidad maximizadora del sistema de derechos esenciales 
o humanos, todo lo que está reconocido en el artículo 29 de la Convención Americana de Derecho Humanos y en el artículo $5^{\circ}$ del Pacto Internacional de Derechos Civiles y Políticos de Naciones Unidas.

El intérprete constitucional debe entender que existe una retroalimentación recíproca entre fuente interna y fuente internacional recepcionada internamente en materia de derechos fundamentales. En la misma perspectiva debe existir una retroalimentación entre el intérprete final del derecho interno y el intérprete final del derecho regional o internacional de derechos humanos, especialmente, de aquel que el Estado se ha comprometido a respetar y garantizar ante la comunidad internacional.

\section{La doctrina constitucional sobre la limitación del ejercicio de la soberanía por los derechos esenciales.}

Dicha perspectiva ha sido asumida también por don Alejandro Silva Bascuñan en su Tratado de Derecho Constitucional, donde afirma que el exacto alcance del artículo $5^{\circ}$, inciso segundo, oración final, es que "la obligación que impone al Estado tiene como ámbito todos esos derechos esenciales y, por lo tanto, no solo aquellos que explícitamente están reconocidos por la Ley Fundamental"1.

El profesor Silva Bascuñan concuerda con Cecilia Medina, además, en que "Si la comunidad internacional, o la nacional, se ponen de acuerdo en que ciertos derechos son 'humanos'o 'esenciales', ellos podrán ser invocados por sus titulares sin necesidad de verse expuestos a probar su naturaleza; ella ya está determinada de antemano y en forma fehaciente"2. Criterios que son reafirmados en el tomo XI del tratado, publicado en 2006, donde hace referencia a la materia en los párrafos 83 a 86 del Tomo IV³ .

El profesor Francisco Cumplido, ha señalado sobre la reforma constitucional de 1989 al artículo $5^{\circ}$, inciso $2^{\circ}$ :

"Para nosotros habría sido mucho mas técnicamente preciso incorporar a la Constitución todos los derechos humanos asegurados por tratados internacionales. Pero nos encontramos con que debíamos concordar la reforma

Silva Bascuñan, Alejandro. Tratado de derecho Constitucional. Tomo IV. Ed. Jurídica de Chile, Santiago, 1997, p. 111.

2 Silva Bascuñan, Alejandro. Tratado de Derecho Constitucional. Tomo IV. Ed. Jurídica de Chile, Santiago, 1997, p. 111.

Silva Bascuñan, Alejandro. Tratado de Derecho Constitucional. Tomo XI. Ed. Jurídica de Chile, Santiago, 2006, p. 15. 
en un tiempo muy breve. Por consiguiente, nos pusimos de acuerdo para que en la aprobación de esta reforma al artículo $5^{\circ}$, los derechos esenciales contenidos en los tratados internacionales ratificados por chile y vigentes, que conocía el constituyente - La junta de Gobierno en ese momento - y que conocían los negociadores, se entendiera que pasaban a formar parte de la Constitución Politica de 1980"4.

Así lo entiende también José Luis Cea Egaña, Ministro y ex Presidente del Tribunal Constitucional, en su obra Derecho Constitucional Chileno, donde afirma:

“En virtud del artículo $5^{\circ}$ inciso $2^{\circ}$, modificado en 1989, la Constitución hace parte formal y sustantiva de su texto los derechos, deberes, acciones y recursos contemplados en los tratados internacionales ratificados por Chile y vigentes en nuestro país que versen sobre los atributos esenciales de la persona humana. "Existe complementación, y no oposición, por ende, entre el Estatuto de la Persona en el derecho interno y en el derecho supranacional. Consecuentemente también, se ha vigorizado aquel estatuto por la conjugación o armonía de ambos sistemas jurídicos. Trátese de una evidencia más acerca de la nueva concepción de la soberanía, limitada y limitable por el respeto que debe al ejercicio de aquellos derechos" 5 .

De acuerdo a tal perspectiva, los derechos de fuente directamente constitucional, como asimismo, los derechos implícitos y los derechos de fuente internacional, constituyen un único bloque de derechos que se retroalimenta recíprocamente, en un sentido de progresividad y aplicando el principio favor persona, lo que posibilita que dimensiones o atributos de los derechos considerados inherentes a la persona o derivados de su dignidad humana que se encuentran asegurados por fuente internacional, sin derogar los derechos directamente constitucionales, pueden incorporarse como parte de ellos si aseguran o garantizan ámbitos de tales derechos que no estaban asegurados explícitamente por la norma constitucional.

Así este bloque de derechos esenciales, interpretados de acuerdo a las reglas y postulados de interpretación de los derechos humanos, constituyen parámetro de control de constitucionalidad de las normas internas infraconstitucionales. Así lo comprendió también el profesor Jaime Guzmán Errázuriz, el cual sostuvo en la Comisión de Estudios de la Nueva

$4 \quad$ Cumplido Cereceda, Francisco. "Los Tratados Internacionales y el artículo $5^{\circ}$ de la Constitución.", en Revista Ius et Praxis, Año $2 \mathrm{~N}^{\circ}$ 2, 1997, Facultad de Ciencias Jurídicas y Sociales, Universidad de Talca, Talca, Chile, pp. 95-96.

5 Cea Egaña, José Luis. Derecho constitucional chileno. Tomo I. Ed. Universidad Católica de Chile, Santiago, 2002. p. 113. 
Constitución que tales derechos posibilitaban el desarrollo de un recurso de inaplicabilidad por inconstitucionalidad.

\section{La jurisprudencia de la Corte Suprema y del Tribunal Constitucional sobre la materia.}

La Corte Suprema de Justicia afirma con claridad que la soberanía, incluido el poder constituyente y todo órgano o autoridad, está limitada por los derechos esenciales de la persona humana, a través de diversos fallos:

"Que en la historia fidedigna del establecimiento de la norma constitucional del artículo $5^{\circ}$ inciso segundo, queda claramente establecido que la soberanía interna del Estado de Chile reconoce como límite los derechos que emanan de la naturaleza humana; valores que son superiores a toda norma que puedan imponer las autoridades del Estado, incluido el propio Poder Constituyente, lo que impiden sean desconocidos (Fallos del Mes No 446, sección criminal, página 2066, considerando $4^{\circ}$ )"6 .

"Que, como lo ha señalado esta misma Corte Suprema en reiteradas sentencias, de la historia fidedigna del establecimiento de la norma fundamental contenida en el artículo $5^{\circ}$ de la Carta Fundamental, queda claramente establecido que la soberanía interna del Estado de Chile reconoce su límite en los derechos que emanan de la naturaleza humana, 'valores que son superiores a toda norma que puedan disponer las autoridades del Estado, incluido el propio poder constituyente, lo que impide sean desconocidos' (S.C.S. 30.1.2006)”? .

En la materia existe una larga lista de precedentes establecidos por la Corte Suprema de Justicia, entre ellos el siguiente:

"Trigésimonono: [...] En definitiva los derechos humanos asegurados en un tratado se incorporan al ordenamiento jurídico interno, formando parte de la Constitución material adquiriendo plena vigencia, validez y eficacia jurídica, no pudiendo ningún órgano del Estado desconocerlos y debiendo todos ellos respetarlos y promoverlos, como asimismo, protegerlos a través del conjunto de garantías constitucionales destinadas a asegurar el pleno respeto de los derechos. Esta obligación no sólo deriva del mentado artículo $5^{\circ}$, sino también del $1^{\circ}$, incisos primero y cuarto, y $19, N^{\circ} 26^{\circ}$, de la Carta Magna y de los mismos

$6 \quad$ Sentencia de la Corte Suprema, Rol No 469-98, de fecha 9 de septiembre de 1998, citado por Cea Egaña, José Luis. Derecho Constitucional Chileno. Tomo I, página 236.

Sentencia de la Corte Suprema, Rol N $559-04$, de fecha 13 de diciembre de 2006, considerando $22^{\circ}$. 
tratados internacionales, entre éstos del artículo $1^{\circ}$ común a los Cuatro Convenios de Ginebra, que establece el deber de los Estados Partes de respetar $y$ hacer respetar el derecho internacional humanitario.

Este carácter amplio de protección se desprende de la historia fidedigna del establecimiento del precepto aludido, puesto que su integrante Jaime Guzmán Errázuriz al recalcar que los derechos que arrancan de la naturaleza humana era "el único límite a la soberanía desde un ángulo objetivo, habida consideración que el debe proyectarse conceptualmente con la noción de bien común”, de tal suerte que aun cuando esos derechos no estén en el texto constitucional "no por eso una disposición jurídica cualquiera que atentara indebidamente en contra de ellos, dejaría de ser ilegítima" (Actas de la Comisión de Estudios de la Nueva Constitución, sesión 49 de veintisiete de junio de mil novecientos setenta y cuatro)" ${ }^{8}$.

En materia de otro derecho esencial, la Corte Suprema ha utilizado la misma línea argumental:

Décimo: Que, a lo anterior, y conforme la norma de reenvío contenida en el artículo $5^{\circ}$ de la Constitución, debe extenderse el reconocimiento con rango constitucional del derecho de defensa, también a los derechos garantizados por los tratados internacionales ratificados por Chile y que se encuentren vigentes como son los artículos 11.1 de la Declaración Universal de Derechos Humanos [...]; el artículo 14.3 del Pacto Internacional de Derechos Civiles y Políticos [...]; el artículo 8.2 de la Convención Americana de Derechos Humanos [...]"9.

Esta misma línea argumental ha sido desarrollada por nuestro Tribunal Constitucional, el cual precisa que:

“[...] el respeto y promoción de los derechos esenciales del hombre, que son superiores y anteriores al Estado y a la Constitución, que no los crea sino que reconoce y asegura", agregando que "estos preceptos no son meramente declarativos sino que constituyen disposiciones expresas que obligan a gobernantes y gobernados tanto en si mismas, como también, en cuanto normas rectoras y vitales que coadyuvan a desentrañar el verdadero sentido y espíritu

$8 \quad$ Sentencia de la Corte Suprema de Justicia, Sala Penal, Rol No 3125 - 04, de fecha 13 de marzo de 2007. Las negritas son nuestras.

9 Sentencia de la Corte Suprema de Justicia de 18 de abril de 2007 . Rol № 4.183 -06, considerandos noveno y décimo. Las negritas son nuestras. 
de las disposiciones de la Constitución” ${ }^{10}$.

Como el mismo Tribunal Constitucional ha explicitado:

$55^{\circ}$ [... " Como ha señalado el Comité de Derechos Humanos de la Organización de las Naciones Unidas, en su Observación General sobre el artículo $6^{\circ}$ del Pacto Internacional sobre Derechos Civiles y Políticos, el derecho a la vida es "el derecho supremo respecto del cual no se autoriza suspensión alguna, ni siquiera en situaciones que pongan en peligro la vida de la nación”. Ha agregado, asimismo, que "el derecho a la vida es el más esencial de estos derechos".

"56: Que el derecho a la vida asegurado por el artículo $19 N^{\circ} 1$ de la Constitución, en consonancia con el artículo $3^{\circ}$ de la Declaración Universal de los Derechos Humanos; el artículo 6.1 del Pacto Internacional de Derechos Civiles y Políticos; el artículo $1^{\circ}$ de la Declaración Americana de los Derechos y Deberes del Hombre, y el artículo $4^{\circ}$ de la Convención Americana de Derechos Humanos, asegura a toda persona -incluyendo al nasciturus- el derecho a mantener la vida y a conservarla frente a los demás hombres. Si se quiere, "es el derecho a que nadie nos la quite, y a que no pueda suprimirla ni cercenarla su propio sujeto" (José Joaquín Ugarte Godoy. El derecho a la vida y la Constitución. Revista Chilena de Derecho, Volumen 33, N³3, 2006, p. 514)."11.

\section{Obligación de adecuar el ordenamiento jurídico nacional al respeto y promoción de los derechos asegurados por la CADH.}

Cabe explicitar que el artículo $2^{\circ}$ de la Convención Americana sobre Derechos Humanos establece el deber del Estado Parte de adecuar su ordenamiento jurídico, a partir de la Constitución, y siguiendo por las leyes, a los derechos que se ha comprometido respetar de acuerdo al artículo $1^{\circ}$ de la misma Convención, derechos que como lo ha sostenido la jurisprudencia uniforme de la Corte Interamericana de Derechos Humanos, son de ejecución directa e inmediata, especialmente, en el caso del derecho a la vida.

\section{Reforma constitucional de 2005 en materia de tratados internacionales.}

Por otra parte, en el plano del derecho interno, debe explicitarse que, de acuerdo con la reforma constitucional de 2005, el artículo 54, en su inciso sexto del texto reformado introduce un principio de grandes repercusiones en el derecho interno y que es plenamente armónico con las obligaciones internacionales asumidas por el Estado Chileno en la Convención de Viena

Sentencia del Tribunal Constitucional, Rol N 943-07-INA, de 10 de junio de 2008, considerando $16^{\circ}$.

Sentencia del Tribunal Constitucional, Rol No 740-07, de fecha 18 de abril de 2008 , considerandos $55^{\circ}$ y $56^{\circ}$. 
sobre Derecho de los Tratados de 1969, ratificada en 1981 y publicada en junio de 1981. Dicho inciso precisa:

"Las disposiciones de un tratado sólo podrán ser derogadas, modificadas o suspendidas en la forma prevista en los propios tratados o de acuerdo a las normas generales de Derecho Internacional."

De acuerdo con esta disposición constitucional el Estado chileno no deja ninguna duda sobre la voluntad de hacer efectivas las obligaciones de ius cogens de cumplir de buena fe las obligaciones internacionales contenidas en los artículos 26 y 27 de la Convención de Viena sobre Derecho de los Tratados (principios Pacta Sunt Servanda y Bonna Fide), como asimismo la obligación de no oponer obstáculos de derecho interno al cumplimiento de las obligaciones internacionales voluntaria y libremente aceptadas, generando responsabilidad internacional por ello.

Una vez que el tratado internacional se encuentra aprobado por el Congreso Nacional y ratificado por el Presidente de la República, genera inmediatamente las obligaciones pertinentes para el Estado si tales tratados están vigentes en el derecho internacional, ellos pasan a ser derecho interno sin dejar de ser derecho internacional, pero, a diferencia de las normas generadas por fuente interna no son susceptibles de derogación por voluntad unilateral del Estado, teniendo aplicación preferente sobre el derecho interno de acuerdo a lo que el Estado ha consentido libre y voluntariamente. Dicha perspectiva fue expresamente asumida por el gobierno y los diversos sectores representados en el Senado en el primer trámite constitucional de la reforma constitucional de $2005^{12}$.

El Tribunal Constitucional en sentencia Rol No 288 de 24 de junio de 1999, respecto del requerimiento formulado respecto del Acuerdo entre Chile y Argentina sobre límites desde el monte Fitz Roy hasta el cerro Daudet, determinó que "el tratado y la ley son fuentes del derecho diferentes" (considerando $6^{\circ}$ ), asimismo ha afirmado que "después de la ratificación formal, el Estado se encuentra obligado a respetar sus cláusulas" (considerando $14^{\circ}$ ).

La Corte Suprema de Justicia, en fallo de fecha 26 de octubre de 1995, ha afirmado que la prescindencia de aplicación de normas de derechos humanos contenidas en tratados internacionales compromete la seguridad y honor del Estado de Chile y debilita el Estado de Derecho, no pudiendo invocarse el derecho interno para incumplir obligaciones internacionales:

"Que se comprometería la seguridad y honor del Estado de Chile ante la comunidad internacional, como se destaca en la sentencia recurrida, si este

12 Segundo Informe de la Comisión de Constitución, Legislación y Justicia del Senado, pp. 188 y siguientes. 
Tribunal efectivamente prescindiera de aplicar las normas internacionales cuando ello fuera procedente. Pues, es un principio reconocido universalmente que las naciones civilizadas no pueden invocar su derecho interno para eludir las obligaciones y compromisos internacionales asumidos por dichos tratados, lo que, ciertamente, de producirse debilitaría el Estado de Derecho"13.

A su vez, la desvinculación de Chile de un tratado internacional está específicamente señalado por la Constitución en el mismo artículo $44 \mathrm{~N}^{\circ} 1$, inciso $7^{\circ}$ :

"Corresponde al Presidente de la República la facultad exclusiva para denunciar un tratado o retirarse de él, para lo cual pedirá la opinión de ambas Cámaras del Congreso, en el caso de tratados que hayan sido aprobados por éste. Una vez que la denuncia o el retiro produzca sus efectos en conformidad a lo establecido en el tratado internacional, éste dejará de tener efecto en el orden jurídico chileno.”

En efecto, de acuerdo con esta disposición queda meridianamente claro que el Estado sólo puede desvincularse de cumplir sus obligaciones internacionales convertidas también en derecho interno obligatorio para todos los órganos estatales y los particulares a través de la denuncia del tratado en la medida que su propia naturaleza lo permita, y una vez cumplidas todas las etapas exigidas por el derecho internacional, sólo una vez que el derecho internacional y sus órganos jurisdiccionales de aplicación en su caso, determinen la liberación del Estado chileno de las obligaciones contenidas en el tratado, este podrá dejar de ser aplicado en el derecho interno.

\section{Conclusiones.}

El restablecimiento de la pena de muerte para determinados delitos por el proyecto de ley en análisis, respecto de los cuales se eliminó de nuestro ordenamiento jurídico dicha pena, implica violar los artículos 1, 2 y 4 de la CADH, con la consiguiente responsabilidad internacional, además de las decisiones jurisprudenciales vinculantes de la Corte Interamericana de Derechos Humanos, como asimismo, implicaría violar el contenido del derecho a la vida constitucionalmente garantizado por los artículos $19 \mathrm{n}^{\circ} 1 ; 5^{\circ}$ inciso $2^{\circ}$; y $19 \mathrm{~N}^{\circ} 26$, en armonía con el artículo $4^{\circ}$ de la CADH, lo que afectaría la constitucionalidad de tal disposición legal.

La única posibilidad de dar curso constitucional al proyecto de ley en análisis implica la previa denuncia de la Convención Americana sobre Derechos Humanos, esperando luego el

13 Sentencia de la Corte Suprema de Justicia, considerando $14^{\circ}$. 
curso de un año exigido desde el momento de la desvinculación, para poder concretar la tramitación válida y legítima del proyecto, todo ello sin perjuicio de las otras obligaciones internacionales aprobadas por el Estado de Chile referentes a la misma materia, entre ellas las convenciones sobre proscripción de la pena de muerte.

Es cuanto puedo informar a vuestra Comisión. 
Revista IUs et PraXis - AÑo 15 - № 2317 